\title{
Preweaned heifer management on US dairy operations: Part VI. Factors associated with average daily gain in preweaned dairy heifer calves
}

\author{
C. B. Shivley, ${ }^{\dagger}$ J. E. Lombard, $\uparrow \ddagger^{1}$ N. J. Urie, $\ddagger$ C. A. Kopral, † M. Santin,§ T. J. Earleywine,\# J. D. Olson,॥ \\ and F. B. Garrył \\ ${ }^{*}$ Department of Animal Sciences, College of Agricultural Sciences, Colorado State University, Fort Collins 80523-1171 \\ †USDA-Animal and Plant Health Inspection Service (APHIS)-Veterinary Services (VS) Center for Epidemiology and Animal Health, \\ National Animal Health Monitoring System, Fort Collins, CO 80526-8117 \\ ‡Department of Clinical Sciences, College of Veterinary Medicine and Biomedical Sciences, Colorado State University, Fort Collins 80523-1678 \\ $\S$ Environmental Microbial and Food Safety Laboratory, USDA, Agricultural Research Service, Beltsville, MD 20705 \\ \#Land O'Lakes Animal Milk Products Co., Cottage Grove, WI 53527 \\ \|Zoetis, 5 Giralda Farms, Madison, NJ 07940
}

\begin{abstract}
The study objective was to evaluate average daily gain (ADG) in dairy heifer calves based on health, feeding, management practices, and environmental factors. This study included 102 operations in 13 states that participated in the calf component of the National Animal Health Monitoring System's Dairy 2014 study. This 18-mo longitudinal study included 1,410 Holstein heifer calves monitored from birth to weaning. The mean ADG from birth to final weight was $0.74 \mathrm{~kg} / \mathrm{d}$. Backward elimination model selection in Proc Mixed after univariate screening determined factors that significantly affected ADG. The final model included dam lactation number, singleton versus twin birth, bedding type, Giardia and Cryptosporidium fecal shedding, disease events, a categorized average temperaturehumidity index for the preweaning period (pTHI), amount of protein in the liquid diet $(\mathrm{kg} / \mathrm{d})$, milk pasteurization, direct-fed microbials, and the interaction between milk pasteurization and direct-fed microbials. After controlling for other independent variables in the model, calves born to first-lactation dams gained less $(0.60 \mathrm{~kg} / \mathrm{d})$ than calves from second- $(0.65 \mathrm{~kg} / \mathrm{d})$ or third- or greater-lactation $(0.64 \mathrm{~kg} / \mathrm{d})$ dams. Singleton calves gained $0.07 \mathrm{~kg} / \mathrm{d}$ more than twins. Calves bedded with sand or no bedding gained less $(0.49 \mathrm{~kg} / \mathrm{d})$ than calves on all other bedding types. Calves negative for Cryptosporidium or Giardia at the time of sampling gained 0.03 or $0.02 \mathrm{~kg} / \mathrm{d}$ more, respectively, than calves that were positive for Cryptosporidium or Giardia. Calves with no disease events gained $0.07 \mathrm{~kg} / \mathrm{d}$ more
\end{abstract}

Received October 18, 2017.

Accepted April 14, 2018.

${ }^{1}$ Corresponding author: Jason.E.Lombard@aphis.usda.gov than calves with one or more disease events. Calves experiencing an average pTHI $<50$ gained more $(0.67$ $\mathrm{kg} / \mathrm{d}$ ) than calves experiencing an average pTHI from 50 to $69(0.62 \mathrm{~kg} / \mathrm{d})$, or $\geq 70(0.59 \mathrm{~kg} / \mathrm{d})$. Within the range of observed kilograms of protein fed per day in the liquid diet, every additional $0.1 \mathrm{~kg}$ of protein fed per day equated to $0.02 \mathrm{~kg} / \mathrm{d}$ of gain. Calves fed milk replacer with a direct-fed microbial gained less $(0.44$ $\mathrm{kg} / \mathrm{d})$ than calves fed milk replacer without a directfed microbial $(0.60 \mathrm{~kg} / \mathrm{d})$ and calves fed pasteurized or unpasteurized milk regardless of direct-fed microbial use. These results highlight the importance of feeding a quantity and quality of a liquid diet to achieve optimal growth, keeping calves free of disease, the type or status of bedding, and mitigating the effects of temperature and humidity on preweaning ADG.

Key words: average daily gain, Holstein heifer calves, liquid diet

\section{INTRODUCTION}

The preweaning phase is a critical period in the life of a dairy heifer, and optimal conditions increase the likelihood of success as a lactating cow. Growth determines the age at first breeding and age and weight at first calving, and is associated with lifetime productivity (Heinrichs, 1993; Soberon et al., 2012; Soberon and Van Amburgh, 2013). Growth during the preweaning period, and specifically ADG, is affected by many different factors, including passive transfer of immunity, disease, nutrition, management practices, and environmental factors (Place et al., 1998). Therefore, ADG is an appropriate metric to evaluate growth and health during the preweaning period.

Proper calf nutrition, defined by the energy and protein available in the diet, is essential for growth and rumen development. At birth, calves are functional 
monogastrics, and they rely exclusively on fluid milk diets for nutrients (Drackley, 2008). During the first 2 wk of life, calves typically just nibble calf starter; by about 3 wk of age, calves should increase their intake of calf starter to approximately $1.4 \mathrm{~kg} / \mathrm{d}$ to stimulate rumen development. Industry recommendations state that calf starter should be offered by $4 \mathrm{~d}$ of age (BAMN, 2003, 2017). Calves must have access to fresh, clean water in addition to the milk diet to stimulate starter feed intake and rumen development (Kertz et al., 1984; BAMN, 2003, 2017). Protein is considered the rate-limiting nutrient for calf growth (Drackley, 2008). Feeding $4 \mathrm{~L}$ of a $20 \%$ protein, $20 \%$ fat milk replacer (MR) provides enough protein and energy for a $50-\mathrm{kg}$ calf under thermoneutral conditions to gain $0.3 \mathrm{~kg} / \mathrm{d}$; feeding the same calf fed $4 \mathrm{~L}$ of a $25 \%$ protein, $20 \%$ fat MR would result in gain of $0.8 \mathrm{~kg} / \mathrm{d}$ (NRC, 2001). Calves are most efficient at converting feed nutrients to body mass during the preweaning period; then, feed efficiency steadily declines as they age, and maintenance requirements increase as they grow (Owens et al., 1993; Kertz et al., 1998). Thus, it is important to try to optimize growth during this period.

Historically, calf feeding regimens included twice-daily feeding of $10 \%$ of BW total, equating to about $2 \mathrm{~L}$ of the liquid diet fed twice per day (Thickett et al., 1986). A rationale for limit-feeding milk has been to promote starter intake, allowing calves to be weaned earlier, but at a cost in terms of health and growth. Limiting the liquid diet fed results in decreased growth (Flower and Weary, 2001), and reducing the nutrient density may increase the incidence of disease in preweaning calves (Godden et al., 2005). More recently, enhanced feeding programs using MR with a higher percent of protein or ad libitum feeding programs using automated calf feeding systems have gained popularity (Jasper and Weary, 2002; Terré et al., 2009).

The objective of this study was to evaluate the association of different health, feeding, and management practices, as well as environmental factors on ADG in preweaned heifer calves.

\section{MATERIALS AND METHODS}

\section{Study Design}

The USDA National Animal Health Monitoring System (NAHMS) conducts national surveys to collect information on the health, management, and productivity of domestic livestock species (USDA, 2016). In 2014, a nationwide survey was conducted to collect information about the US dairy industry, including an 18-mo longitudinal preweaned dairy heifer calf study. All participation in NAHMS studies is voluntary.
However, to participate in the longitudinal calf study, operations had to have completed both NAHMS Dairy 2014 surveys and agreed to provide information on enrolled calves, whether raised onsite or offsite.

The calf component of the NAHMS Dairy 2014 study consisted of a convenience sample of 102 dairy operations with Holstein calves, including both conventional and organic operations. These operations were located in 13 states, including California, Colorado, and Washington in the western region, and Iowa, Michigan, Minnesota, Missouri, New York, Ohio, Pennsylvania, Vermont, Virginia, and Wisconsin in the eastern region. Dairy operations were categorized based on the number of mature cows, as small (30-99 cows), medium (100-499 cows), and large ( $\geq 500$ cows).

Data collection for the calf component of the study occurred from March 2014 through September 2015. Data collectors were trained on data and sample collection. Each operation was instructed to enroll 24 heifer calves over a 1-yr period, or an average of 2 calves per month. Farm personnel selected which calves to enroll in the study. However, a calf must have been alive at 24 $\mathrm{h}$ of age to be enrolled. Because fewer operations agreed to participate than originally planned, the number of calves that could be enrolled was increased to 48 to 60 calves per operation. Additionally, because enrollment of farms did not occur as quickly as anticipated, the study encompassed 18 mo instead of the 12 -mo period initially planned.

\section{Heifer Calf Health Card}

Each calf enrolled in the study had a Heifer Calf Health Card (Calf Card) filled out to record information on events that occurred between birth and weaning (https://www.aphis.usda.gov/animal_health/nahms/ dairy/downloads/dairy14ques/CalfHealth.pdf). The Calf Card contained questions in both English and Spanish and was filled out by farm personnel, a veterinary medical officer, extension personnel, veterinarians, or a combination of people involved with calf raising. Sections of the Calf Card included birth data (such as birth date, weight, and calving ease); colostrum feeding data (including timing, volume, and method of colostrum feeding); preweaning housing and procedure data (such as housing, ventilation, bedding, and dehorning); milk feeding (including type of liquid diet fed, any additives, and method of feeding); milk consumption record (amount and frequency of feedings); preweaning growth record (hip height and heart girth recordings every 2 wk); biologic sampling record (including serum collection and fecal sampling dates); vaccinations; disease incidence and treatment; weaning data (weaning date, primary weaning criteria); and any additional notes. 
Additional information requested included starter feed labels and MR feed labels (if applicable).

Producers were provided with the Calf Health Scoring Chart (https://www.vetmed.wisc.edu/dms/fapm/ apps/chs.htm) to guide the reporting of clinical signs. The goal of the study was to collect recognized clinical signs and causes of death, not to standardize clinical signs and causes of death across operations.

Because of the variation observed in the quantity and quality of the liquid diet fed per day, kilograms of protein and fat fed per day were calculated for each calf. Information regarding the amount of liquid diet fed per feeding and the frequency of feedings per day were recorded on the Calf Card and used to calculate the total amount of liquid diet fed. For calves fed MR, the percent protein and percent fat were obtained from the producer-reported values or the MR label. For calves fed whole or waste milk, percent protein was set at $3.1 \%$ and percent fat as $3.8 \%$ (as-fed basis; Chester-Jones and Hoffman, 2003). The total amount of protein and fat were calculated, and then divided by the number of days the liquid diet was fed to determine the average kilograms of protein and fat fed per day in the liquid diet.

Additives in the liquid diet were categorized as antibiotics, direct-fed microbials (DFM), or other additives, which included fly control, organic acids (as preservatives), and coccidiostats. Information regarding calf starter included the percent protein and the age starter was first offered, but starter intake was not recorded.

\section{Biological Sampling and Testing}

Before being enrolled in the study, calves were screened for persistent infection with bovine viral diarrhea virus (BVDV). V-Cut ear notchers (Nasco, Fort Atkinson, WI) were used to collect ear notch samples from all calves, which were tested on-farm for BVDV using the Idexx SNAP BVDV Antigen Test (Idexx, Westbrook, ME). Calves positive for BVDV were not enrolled in the study. Colostrum samples (40-50 mL) from the first feeding of colostrum administered to the calf were collected in conical screw-top tubes by farm personnel, and then frozen until shipping. Serum samples $(5 \mathrm{~mL})$ from calves between 1 and $7 \mathrm{~d}$ of age were collected in serum separator tubes by veterinary medical officers (VMO) or animal health technicians (AHT), and samples were centrifuged if possible before shipping. Colostrum and serum samples were shipped together on ice to USDA's National Veterinary Services Laboratories (Ames, IA). Samples were then accumulated and shipped in bulk to the Saskatoon Colostrum Co. (Saskatoon, SK, Canada). Blood samples collected within $24 \mathrm{~h}$ of birth or after $7 \mathrm{~d}$ of age were excluded from this analysis. A complete description of the methods used for Brix scoring and IgG determination can be found in Urie et al. (2018).

For the evaluation of enteric parasites, VMO and AHT collected approximately $50 \mathrm{~g}$ of feces directly from the rectum of calves between 2 and 4 wk of age and placed the samples in cylindrical screw-top containers. Fecal samples were shipped on ice to USDA Agricultural Research Service's Environmental Microbial Food Safety Laboratory (Beltsville, MD) as quickly as possible after sample collection. Fecal samples were tested by immunofluorescence microscopy for Cryptosporidium parvum and Giardia duodenalis. A complete description of the methods used for fecal parasite testing can be found in Urie et al. (2018).

\section{Growth Measurements}

Calves were measured approximately every 2 wk during the preweaning period to monitor growth rates. Height and weight tapes from Coburn (Nasco, Fort Atkinson, WI) were provided for measuring calves. For consistency, it was recommended that one trained VMO or AHT complete the measurements on all calves enrolled on an operation. Birth weights were estimated using either the operation's standard protocol or a weight tape. Hip height and heart girth circumference were measured approximately every 2 wk and recorded in centimeters. Heart girth circumference in centimeters was converted to kilograms using the following equation (Heinrichs et al., 1992):

$$
\begin{aligned}
& \text { BW }(\mathrm{kg})=\left[\left(0.02655 \times \mathrm{cm}^{2}\right)\right. \\
& +(-2.876 \times \mathrm{cm})+102.71] .
\end{aligned}
$$

Preweaning weight gain was calculated by subtracting the birth weight from the final weight. Average daily gain was calculated by taking the weight gain during the preweaning period divided by the number of days between birth weight and final weight (approximately the preweaning period). Final weights did not always occur at the same time as weaning, although only calves with final weight measurements within $14 \mathrm{~d}$ of weaning were included in the analysis. Average daily gain categories were determined based on field experience by one of the authors (TJE), with poor ADG $<0.64 \mathrm{~kg} / \mathrm{d}$, fair ADG $0.64-0.82 \mathrm{~kg} / \mathrm{d}$, and excellent ADG $>0.82 \mathrm{~kg} / \mathrm{d}$.

\section{Environmental Factors}

Temperature-humidity index (THI) data were obtained monthly by county from the National Oceanic 
and Atmospheric Administration (NOAA, 2016); the THI accounts for the effects of temperature and relative humidity, and the equation uses the dry bulb temperature $\left(\mathrm{T},{ }^{\circ} \mathrm{F}\right)$ and the relative humidity $(\mathrm{RH})$. The equation used for this analysis was THI $=\mathrm{T}-[0.55$ $-(0.55 \times \mathrm{RH} / 100) \times(\mathrm{T}-58)]$ (Collier et al., 2011) Each calf was assigned a THI for each month during the preweaning period (pTHI) and then averaged. The average pTHI for each calf was then categorized according to the thermoneutral zone for a calf as follows: $<50$ (cold stress), $\geq 50$ and $<70$ (thermoneutral zone), or $\geq 70$ (heat stress) (Stull and Reynolds, 2008).

Elevation data (in meters) were obtained for each county and state from the National Oceanic and Atmospheric Administration (NOAA, 2016).

\section{Statistical Analysis}

When each calf was weaned, the Calf Card was mailed to NAHMS (Fort Collins, CO). Initial validation was performed on every Calf Card as it came in to check accuracy of dates and other information. Data were then entered into SAS (version 9.4; SAS Institute Inc., Cary, $\mathrm{NC}$ ). Once all Calf Cards were entered, the data were validated again by the NAHMS staff and merged with the results from the colostrum, serum, and fecal testing obtained from the laboratories. Descriptive data were analyzed using the FREQUENCY and MEANS procedures of SAS for categorical and continuous variables, respectively.

A multivariable random effects mixed model was constructed to determine the factors associated with ADG, with operation included as the random variable. Predictor variables were considered for the model based on biological plausibility. To be included in the analysis, only Holstein calves were included, and calves had to have data for all of the variables included in the initial multivariable model. Univariate screening was used to determine which variables to include in the initial model, and variables with a $P<0.20$ were considered for inclusion in the multivariable model. Stepwise backward elimination model selection in PROC MIXED of SAS was used to construct the final model, with variables with $P<0.05$ considered significant and thus included in the model. All first-order interactions of the final model variables were evaluated for significance. Model fit was evaluated using the Akaike information criterion.

\section{RESULTS}

Complete data were available for 1,410 calves from 97 operations in 12 states (Figure 1). The mean ADG was $0.74 \mathrm{~kg} / \mathrm{d}$ (SE 0.01), and calves were fed liquid diets an average of $64.7 \mathrm{~d}$ (SE 0.48; Table 1). Average birth weight was $43.2 \mathrm{~kg}$ (SE 0.14), average final weight was $90.9 \mathrm{~kg}$ (SE 0.56), and average preweaning weight gain was $48.4 \mathrm{~kg}$ (SE 0.53). Overall, $33.3 \%$ of calves had a mean ADG of greater than $0.82 \mathrm{~kg} / \mathrm{d}$.

Initial variables included in the multivariable model for ADG included region, pTHI category, dam lactation, number of calves (single vs. twin), DFM added to liquid diet, coccidiostats in calf starter, producer-reported disease status, Cryptosporidium status, Giardia status, bedding, sex of caretaker, dehorning status, milk pasteurization, birth weight, calf serum IgG, colostrum IgG, kilograms of protein and kilograms of fat in liquid diet per day, frequency of feedings, and number of vaccines (Tables 2 and 3). Although the number of calves in the group and milk delivery system had $P$-values $<0.2$ in the univariate screening, they were excluded from the multivariable model due to a strong correlation with kilograms of protein and fat per day.

The final model included disease status $(P<0.001)$, protein fed in the liquid diet per day $(\mathrm{kg} / \mathrm{d} ; P=0.004)$, milk pasteurization $(P<0.001)$, addition of DFM to the liquid $\operatorname{diet}(P=0.123)$, the interaction between DFM and milk pasteurization $(P<0.001)$, categorized average pTHI $(P<0.001)$, dam lactation number $(P<$ $0.001)$, bedding type $(P<0.001)$, singleton versus twin birth $(P=0.007)$, Cryptosporidium status $(P=0.003)$, and Giardia status $(P=0.020)$ (Table 4$)$. After controlling for other independent variables in the model, calves with no disease events gained $0.07 \mathrm{~kg} / \mathrm{d}$ more than calves with one or more disease events. Within the range of observed kilograms of protein fed per day in the liquid diet, every additional $0.1 \mathrm{~kg}$ of protein fed per day equated to $0.02 \mathrm{~kg} / \mathrm{d}$ of gain. The interaction between diet and DFM showed that calves fed MR with a DFM gained less $(0.44 \mathrm{~kg} / \mathrm{d})$ than calves fed MR without a DFM $(0.60 \mathrm{~kg} / \mathrm{d})$ and calves fed pasteurized or unpasteurized milk with or without a DFM (Table 5; Figure 2). Calves fed pasteurized milk without a DFM gained more $(0.70 \mathrm{~kg} / \mathrm{d})$ than calves fed unpasteurized milk without a DFM $(0.64 \mathrm{~kg} / \mathrm{d})$ and calves fed MR with or without a DFM $(0.44$ and $0.60 \mathrm{~kg} / \mathrm{d}$, respectively). Additionally, calves fed MR without DFM gained less than calves fed unpasteurized milk with a DFM $(0.72 \mathrm{~kg} / \mathrm{d})$. Calves experiencing an average pTHI $<50$ gained more $(0.67 \mathrm{~kg} / \mathrm{d})$ than calves experiencing an average pTHI from 50 to $69(0.62 \mathrm{~kg} / \mathrm{d})$, or $\geq 70(0.59$ $\mathrm{kg} / \mathrm{d})$. Calves born to first-lactation dams gained less $(0.60 \mathrm{~kg} / \mathrm{d})$ than calves from second- $(0.65 \mathrm{~kg} / \mathrm{d})$ or third- or higher-lactation dams $(0.64 \mathrm{~kg} / \mathrm{d})$. Calves bedded with sand or no bedding gained less (0.49 $\mathrm{kg} / \mathrm{d}$ ) than all other bedding types (straw, shavings, or manure biosolids). Single calves gained $0.07 \mathrm{~kg} / \mathrm{d}$ more than twins. Calves negative for Cryptosporidium 
Table 1. General growth parameters for Holstein heifer calves during the preweaning period $(\mathrm{n}=1,410)$

\begin{tabular}{|c|c|c|c|c|c|c|c|}
\hline \multirow[b]{2}{*}{ Parameter } & \multirow[b]{2}{*}{ Mean } & \multirow[b]{2}{*}{$\mathrm{SE}$} & \multicolumn{5}{|c|}{ Percentile } \\
\hline & & & 5 th & 25 th & 50 th & 75 th & 95 th \\
\hline Birth weight (kg) & 43.2 & 0.14 & 36.3 & 39.9 & 42.6 & 45.8 & 52.2 \\
\hline Final weight $(\mathrm{kg})$ & 90.9 & 0.56 & 59.9 & 77.6 & 89.4 & 101.6 & 127.0 \\
\hline Preweaning weight gain $(\mathrm{kg})$ & 48.4 & 0.53 & 20.4 & 34.9 & 46.3 & 58.9 & 85.5 \\
\hline Age at weaning $(d)$ & 64.7 & 0.48 & 43.0 & 56.0 & 61.0 & 70.0 & 100.0 \\
\hline Age at final weight measurement (d) & 64.6 & 0.48 & 43.0 & 56.0 & 61.0 & 71.0 & 93.0 \\
\hline $\mathrm{ADG}^{1}(\mathrm{~kg} / \mathrm{d})$ & 0.74 & 0.01 & 0.4 & 0.6 & 0.7 & 0.9 & 1.1 \\
\hline
\end{tabular}

${ }^{1}$ Calculated by taking the weight gain during the preweaning period divided by the number of days between birth weight and final weight (approximately the preweaning period).

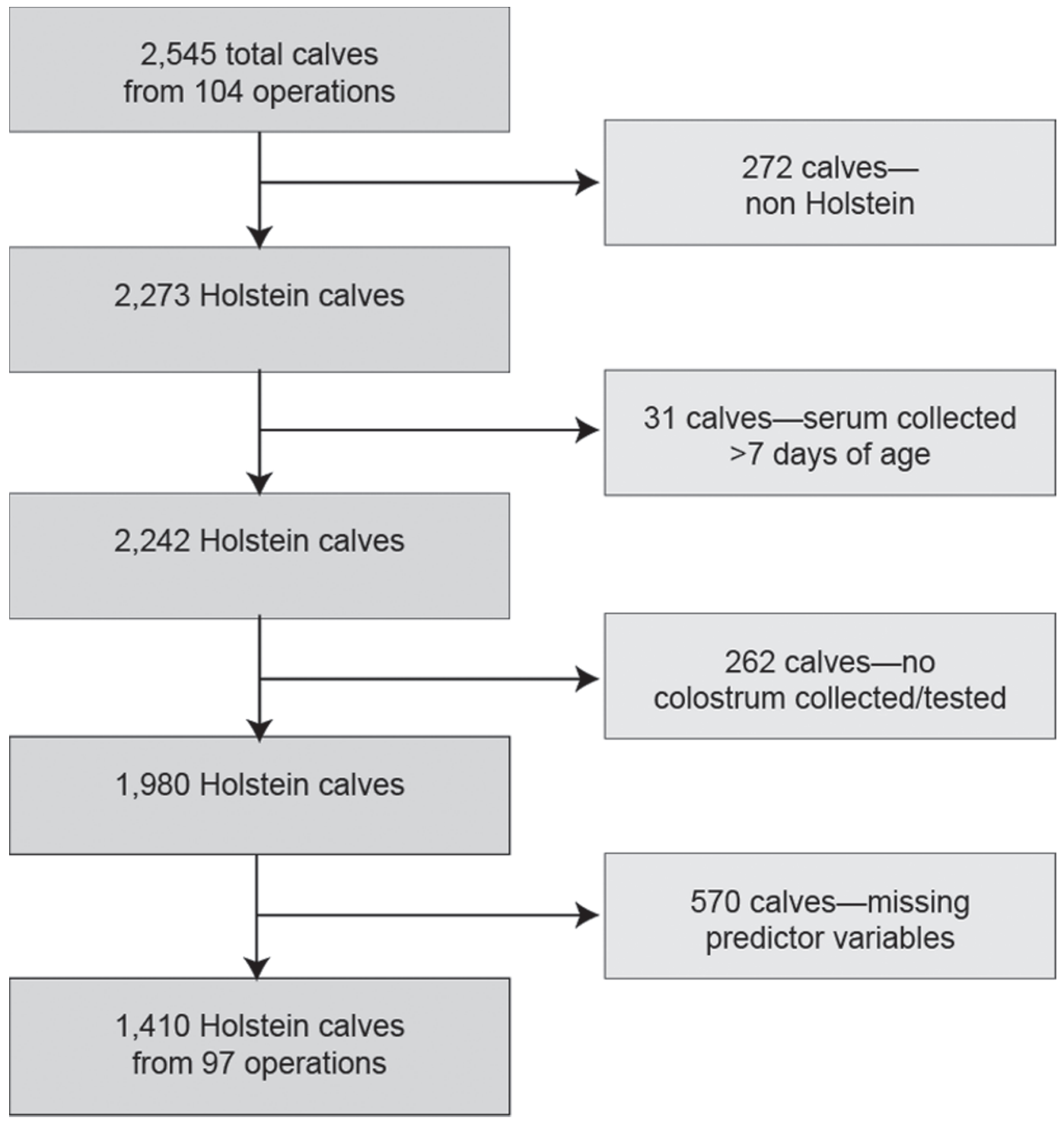

Figure 1. Flowchart summarizing the number of calves used in the ADG model from the overall USDA National Animal Health Monitoring System's (NAHMS) Dairy 2014 study (calf component; USDA, 2016) and reasons for removing calves from the analysis. 
Table 2. Percent of Holstein heifer calves for all categorical variables included in univariate screening for the multivariable ADG model, by ADG category ${ }^{1}$

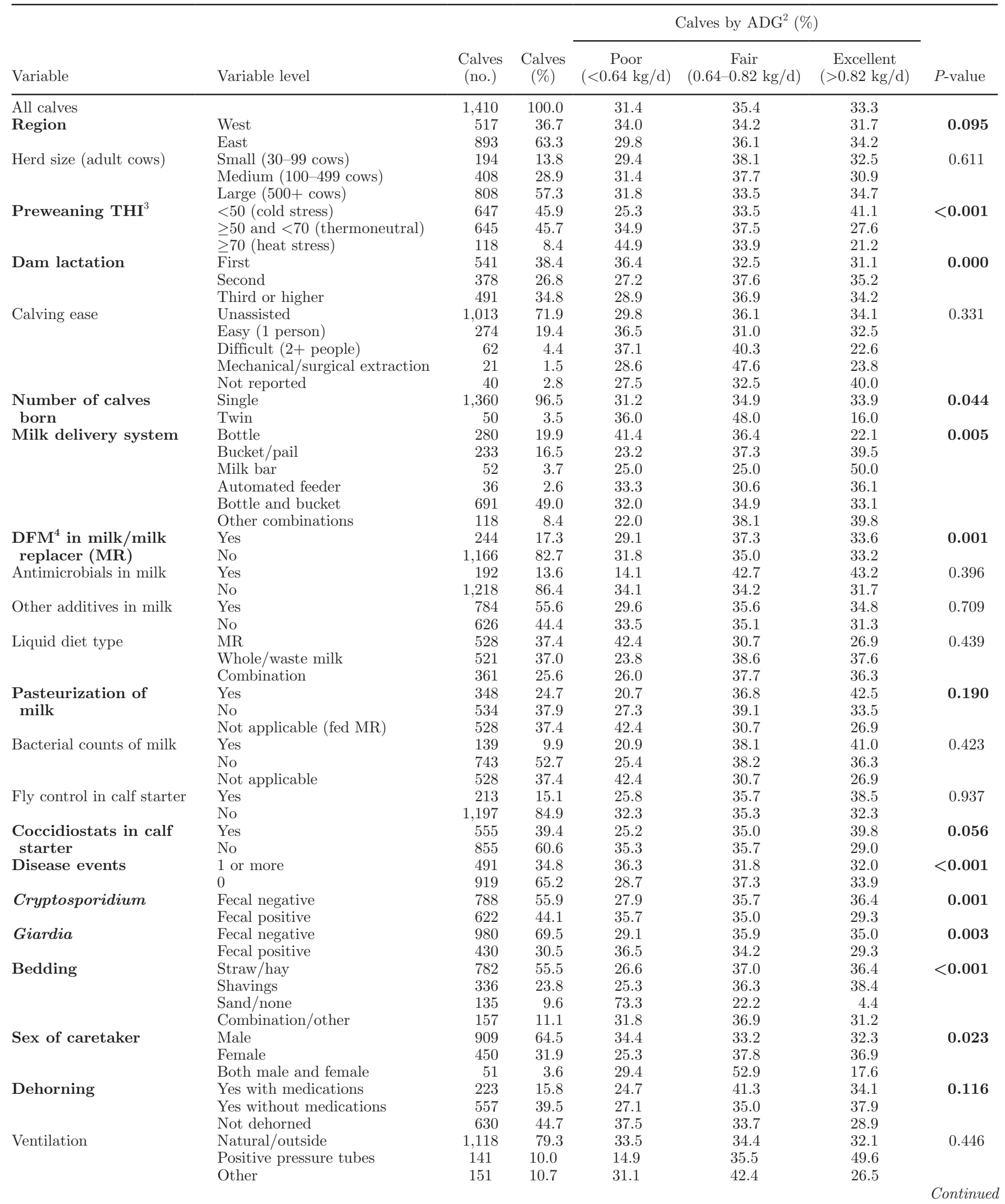


Table 2 (Continued). Percent of Holstein heifer calves for all categorical variables included in univariate screening for the multivariable ADG model, by ADG category ${ }^{1}$

\begin{tabular}{|c|c|c|c|c|c|c|c|}
\hline \multirow[b]{2}{*}{ Variable } & \multirow[b]{2}{*}{ Variable level } & \multirow[b]{2}{*}{$\begin{array}{c}\text { Calves } \\
\text { (no.) }\end{array}$} & \multirow[b]{2}{*}{$\begin{array}{c}\text { Calves } \\
(\%)\end{array}$} & \multicolumn{3}{|c|}{ Calves by $\mathrm{ADG}^{2}(\%)$} & \multirow[b]{2}{*}{$P$-value } \\
\hline & & & & $\begin{array}{c}\text { Poor } \\
(<0.64 \mathrm{~kg} / \mathrm{d})\end{array}$ & $\begin{array}{c}\text { Fair } \\
(0.64-0.82 \mathrm{~kg} / \mathrm{d})\end{array}$ & $\begin{array}{c}\text { Excellent } \\
(>0.82 \mathrm{~kg} / \mathrm{d})\end{array}$ & \\
\hline \multirow[t]{4}{*}{ Weaning criteria } & Starter intake & 44 & 3.1 & 52.3 & 22.7 & 25.0 & 0.271 \\
\hline & Age & 764 & 54.2 & 35.9 & 35.1 & 29.1 & \\
\hline & Lack of space & 84 & 6.0 & 21.4 & 29.8 & 48.8 & \\
\hline & Other & 25 & 1.8 & 24.0 & 24.0 & 52.0 & \\
\hline
\end{tabular}

${ }^{1}$ Bolded variables were included in the initial multivariable ADG model $(P$-value $<0.20)$.

${ }^{2}$ Calculated by taking the weight gain during the preweaning period divided by the number of days between birth weight and final weight (approximately the preweaning period). The cutoff values were determined by one of the authors (TJE).

${ }^{3}$ Temperature-humidity index $(\mathrm{THI})=\mathrm{T}-[0.55-(0.55 \times \mathrm{RH} / 100) \times(\mathrm{T}-58)]$, where $\mathrm{T}=$ dry bulb temperature $\left({ }^{\circ} \mathrm{F}\right) ;$ and $\mathrm{RH}=\operatorname{relative}$ humidity. Each calf was assigned a THI for each month during the preweaning period (pTHI) and then averaged. The average pTHI for each calf was then categorized according to the thermoneutral zone for a calf as follows: $<50$ (cold stress), $\geq 50$ and $<70$ (thermoneutral zone), or $\geq 70$ (heat stress).

${ }^{4}$ Direct-fed microbials.

or Giardia at the time of sampling gained 0.03 or 0.02 $\mathrm{kg} / \mathrm{d}$ more, respectively, than calves that were positive for Cryptosporidium or Giardia.

\section{DISCUSSION}

The results of this study showed that ADG of dairy heifer calves during the preweaning period was influenced by many factors, including disease, kilograms of protein fed per day in the liquid diet, milk pasteurization, the interaction between DFM and milk pasteurization, THI for the preweaning period, dam lactation, bedding type, the number of calves born (single vs. twin), Cryptosporidium status, and Giardia status. As expected, calves with one or more disease events during the preweaning period gained less than calves with no disease events. Previous research has also shown a negative relationship between disease and growth (Virtala et al., 1996; Donovan et al., 1998; Bach, 2011). The 2 most commonly reported clinical signs of disease in this study were digestive and respiratory signs. Disease during the preweaning period can affect ADG by nutrient loss from the diet via diarrhea, diversion of energy to the immune system and away from growth, dehydration, and suppressed appetite and feed intake (Donovan et al., 1998). Disease events were self-reported by producers for this study, and it is possible that some operations were more vigilant about detecting and reporting disease than others. Therefore, the real impact of disease on ADG was probably greater than the results of this study indicate. Ensuring calves are fed the recommended amount of high-quality colostrum immediately after birth for adequate passive transfer of immunity, housing calves in a clean environment, and providing proper nutrition can all help reduce the incidence of disease in calves (LeBlanc et al., 2006), thus improving ADG.

Nutrition during the preweaning period is critical for growth, with both the quantity and the quality of the liquid diet having significant effects (Drackley, 2008; Soberon et al., 2012; Soberon and Van Amburgh, 2013). In one study, calves fed milk ad libitum consumed twice as much milk and gained 4 times as much compared with restricted-fed calves, who also displayed signs of hunger (De Paula Vieira et al., 2008). Increasing the amount of milk fed during the preweaning period can also increase future milk yield (Rincker et al., 2011; Soberon et al., 2012; Soberon and Van Amburgh, 2013; Van Amburgh et al., 2014), as well as decrease the time to first calving (if bred based on weight; Curtis, 2015). According to the National Research Council's energy requirements for calves (NRC, 2001), the ME required for maintenance of a $45-\mathrm{kg}$ calf under thermoneutral conditions is $1.75 \mathrm{Mcal} / \mathrm{d}$, which equates to about $2.5 \mathrm{~L}$ of whole milk or $3.0 \mathrm{~L}$ of an average MR (20\% protein, $20 \%$ fat), because most MR have lower levels of fat than milk (Drackley, 2008). Protein requirements are determined by the desired rate of growth (Drackley, 2008). Because calves in this study were fed varying amounts of liquid diets of differing compositions, the average amount of protein and fat fed to the calf per day were used in the ADG model. The protein and fat per day $(\mathrm{kg})$ were highly correlated, with only protein per day staying in the final model. The results of this study showed that ADG increased with greater amounts of protein fed per day. Similarly, Li et al. (2008) showed that calves fed a high-protein diet had greater ADG than calves fed mid- or low-protein diets. Increasing protein in the diet appears to have a positive linear relationship with BW gain (Blome et al., 2003). Calves fed a higher plane of 
nutrition are able to convert the additional nutrients into lean tissue at high efficiency (Liang et al., 2015b). Increasing the amount of protein in the liquid diet, by either increasing the overall amount of liquid diet fed or increasing the concentration of protein in the liquid diet, improves ADG in dairy heifer calves during the preweaning period.

In this study, calves fed MR gained significantly less than calves fed pasteurized or unpasteurized milk. A survey of on-farm pasteurizers showed that although waste milk composition is highly variable, concentrations of protein and fat are greater than in conventional MR (Jorgensen et al., 2006). Concerns with feeding waste milk include inconsistent composition, bacterial contamination, and antimicrobial residues. A controlled study comparing calves fed pasteurized waste milk versus a $20 \% \mathrm{CP}, 20 \%$ fat conventional MR found that calves fed waste milk had greater weaning weights, higher ADG, and lower morbidity and mortality, possibly due to the higher levels of protein provided (Godden et al., 2005). The higher fat content of milk can have a detrimental effect on starter intake, potentially reducing ADG, as seen by Hill et al. (2009). Not all MR are created equal, and supplementing MR with amino acids and fatty acids can improve ADG (Hill et al., 2007). Perhaps more important than the source of the liquid diet is the amount of total solids consumed by the calf as an indicator of the overall quantity and quality of the liquid diet. Although the quality of MR in terms of percent fat and protein were accounted for in the model, the sources of fat and protein were not controlled for, nor were additional supplements.

Direct-fed microbials, or probiotics, are nonpathogenic microbial species that are added to the diet to improve gastrointestinal flora (BAMN, 2011). In this study, the addition of DFM to the liquid diet resulted in a lower ADG for calves fed MR, but calves fed DFM with unpasteurized milk had higher ADG than calves fed MR without DFM. Although several studies have shown improved growth rates when feeding DFM (Abe et al., 1995; Timmerman et al., 2005; Adams et al., 2008), other studies have shown that DFM had no effect on growth or health (Jenny et al., 1991; Morrill et al., 1995; Abu-Tarboush et al., 1996; Higginbotham et al., 1998). Direct-fed microbials may be most important for calves exposed to pathogens or environmental challenges that lead to stress, disrupting the intestinal flora (BAMN, 2011). Because of this, perhaps calves that were fed DFM in this study were already experiencing stress, which is why the producer decided to add DFM to the diet. The resulting lower ADG detected in this study associated with feeding DFM and MR might be reflecting other challenges on the operation.

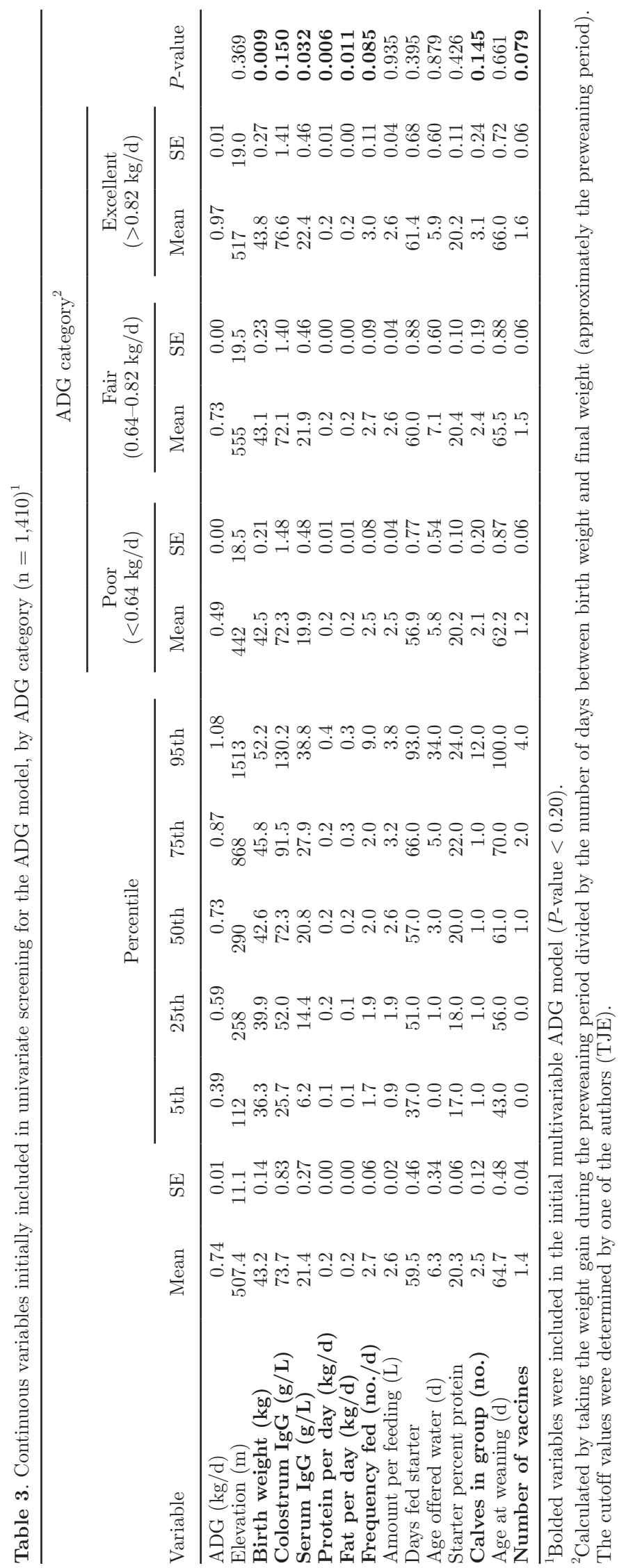


Increasing the plane of nutrition during the preweaning period not only affects ADG but can also lead to better disease resistance. Until recently, few studies evaluating the effects of nutrition on disease had been conducted, though previous work has shown that calves fed less energy and protein than necessary for growth also have higher death losses (Goff, 2006). One study found that the plane of nutrition might modulate functions associated with cell-mediated immune responses, though the study was conducted via ex vivo cell function assays (Nonnecke et al., 2003). Another study showed that Jersey dairy heifers fed a higher plane of nutrition had a higher ADG and were more resistant to Salmonella postweaning (Ballou et al., 2015). In a controlled trial comparing a low plane of nutrition with a high plane of nutrition during the preweaning period, calves were subsequently challenged postweaning with Mannheimia haemolytica or a combined bovine herpesvirus-1 and $M$. haemolytica. The calves fed a low plane of nutrition preweaning responded with more severe disease to the combined viral and bacterial challenge postweaning (Sharon et al., 2015a,b). Lower planes of nutrition during the preweaning period appeared to increase the risk of respiratory disease 1 mo after weaning, indicating that early life nutrition can influence resistance to and pathology of disease (Sharon et al., 2015a,b). Another study found that calves fed a high plane of nutrition during the preweaning period had a greater acute phase response to an opportunistic bacterial enteric infection compared with calves fed a low plane of nutrition (Liang et al., 2015a). Nutrition of calves during the preweaning period is important for immune function and disease susceptibility, in addition to improving growth rates.

Environmental factors were evaluated for influences on ADG, and the average THI during the preweaning period was associated with growth. Calves experiencing an average pTHI of $<50$ gained more than calves experiencing an average pTHI of 50 to 69 or $\geq 70$. Previous research has shown that calf growth is negatively affected by periods of heat stress, with lower starter consumption and lower BW at weaning (Broucek et al., 2009). Decreased blood flow to the digestive tract during periods of heat stress led to decreased absorption of nutrients and decreased feed intake (Beede and Collier, 1986). Any deviation from the thermoneutral

Table 4. Results of multivariable modeling of factors associated with ADG for Holstein heifer calves $(\mathrm{n}=1,410)$

\begin{tabular}{|c|c|c|c|c|c|c|c|}
\hline Variable $^{1}$ & $\begin{array}{l}\text { Factor } \\
P \text {-value }\end{array}$ & Variable level & $\begin{array}{c}\text { Model- } \\
\text { predicted } \\
\text { ADG }(\mathrm{kg} / \mathrm{d})\end{array}$ & $\mathrm{SE}$ & Estimate & $\mathrm{SE}$ & $\begin{array}{l}P \text {-value for } \\
\text { pairwise } \\
\text { comparisons }\end{array}$ \\
\hline \multirow{2}{*}{ Dam lactation } & \multirow{2}{*}{$<0.001$} & Second & 0.65 & 0.02 & 0.008 & 0.01 & 0.521 \\
\hline & & Third or higher & 0.64 & 0.02 & Referent & & \multirow[b]{2}{*}{0.007} \\
\hline Number of calves & 0.007 & Single & 0.66 & 0.02 & 0.070 & 0.03 & \\
\hline & \multirow{3}{*}{$<0.001$} & Shavings & 0.67 & 0.03 & -0.000 & 0.03 & 0.999 \\
\hline & & Sand/none & 0.49 & 0.04 & -0.180 & 0.04 & $<0.001$ \\
\hline & & Combination/other & 0.67 & 0.03 & Referent & & \\
\hline \multirow[t]{2}{*}{ Giardia status } & \multirow[t]{2}{*}{0.020} & Fecal negative & 0.64 & 0.02 & 0.025 & \multirow[t]{2}{*}{0.01} & \multirow[t]{2}{*}{0.020} \\
\hline & & Fecal positive & 0.62 & 0.02 & Referent & & \\
\hline \multirow[t]{2}{*}{ Cryptosporidium status } & \multirow[t]{2}{*}{0.003} & Fecal negative & 0.64 & 0.02 & 0.030 & \multirow[t]{2}{*}{0.01} & \multirow[t]{2}{*}{0.003} \\
\hline & & Fecal positive & 0.61 & 0.02 & Referent & & \\
\hline \multirow{6}{*}{$\begin{array}{l}\text { Interaction between DFM } \\
\text { and milk pasteurization }\end{array}$} & \multirow[t]{6}{*}{$<0.001$} & Pasteurized milk w/ DFM & 0.67 & 0.04 & 0.137 & \multirow[t]{2}{*}{0.05} & \multirow[t]{2}{*}{0.007} \\
\hline & & Pasteurized milk w/o DFM & 0.70 & 0.03 & 0 & & \\
\hline & & Unpasteurized milk w/ DFM & 0.72 & 0.04 & 0.242 & \multirow[t]{4}{*}{0.05} & $<0.001$ \\
\hline & & Unpasteurized milk w/o DFM & 0.64 & 0.02 & 0 & & \\
\hline & & MR w/ DFM & 0.44 & 0.04 & 0 & & \\
\hline & & MR w/o DFM & 0.60 & 0.02 & 0 & & \\
\hline Disease events & $<0.001$ & 1 or more & 0.59 & 0.02 & -0.069 & 0.01 & $<0.001$ \\
\hline & & 0 & 0.66 & 0.02 & Referent & & \\
\hline Preweaning temperature- & $<0.001$ & $<50$ (cold stress) & 0.67 & 0.02 & 0.077 & 0.02 & $<0.001$ \\
\hline humidity index & & $\geq 50$ and $<70$ (thermoneutral) & 0.62 & 0.02 & 0.031 & 0.02 & 0.120 \\
\hline & & $\geq 70$ (heat stress) & 0.59 & 0.03 & Referent & & \\
\hline Protein per day $(\mathrm{kg} / \mathrm{d})$ & 0.004 & & 0.21 & 0.07 & 0.213 & 0.07 & 0.004 \\
\hline
\end{tabular}

${ }^{1} \mathrm{DFM}=$ direct-fed microbial; MR = milk replacer; w/ = "with"; w/o = "without." 
zone for a calf causes some degree of thermal stress (Roland et al., 2016), yet calves seem better able to handle cold stress than heat stress if provided enough nutrition. Maintenance requirements for calves outside of the thermoneutral zone increase (Drackley, 2008), although an increase in starter intake can help the calf meet maintenance requirements. Nonnecke et al. (2009) showed that calves raised in a cold environment had similar gains to calves raised in a warm environment, but the cold calves consumed more starter. When ADG is compared over different seasons, calves in the winter tended to gain the most and calves in the summer tended to gain the least, providing further support for calves adjusting better to cold than to heat stress (Place et al., 1998). This may also be due to increased liquid feeding in cold weather, although this is a more frequent practice now than $20 \mathrm{yr}$ ago, when that study was conducted (Drackley, 2008). Heifers that experience heat stress have increased metabolic requirements, yet this is compounded by decreased appetite and decreased feed intake (West, 2003). The current study was unable to quantify starter intake, but calves raised during colder periods might have consumed more starter than calves raised in the thermoneutral zone or in hot periods, accounting for their increased ADG.
The bedding type used was associated with ADG in this study, with calves bedded with sand or no bedding gaining significantly less than all other bedding types used (including straw, shavings, or manure biosolids). It is interesting that sand bedding was not a good choice for preweaned calves but appears to be the best bedding for cows (Lombard et al., 2010; Andreasen and Forkman, 2012). When given a choice, calves preferred sawdust over concrete, even if the sawdust was wet (Camiloti et al., 2012). Another study showed that calves preferred sawdust over all other bedding types (Worth et al., 2015). One study showed that calves bedded with straw gained more than calves bedded with sand (Hill et al., 2011). Although Panivivat et al. (2004) found no differences in growth between different bedding types, calves housed on sand had more scour treatments and were scored as dirtiest compared with calves on all other bedding types. Calves with more lying bouts tended to have higher gains than calves with fewer lying bouts (Mogensen et al., 1997). By providing calves with a more comfortable environment with bedding substrates other than sand or no bedding, calves likely spend more time lying down, thus improving their growth.

Calves from single births gained more during the preweaning period than calves from twin births. Twin

Table 5. Results of multivariable modeling of interaction between pasteurization of milk and direct-fed microbials and association with ADG in Holstein heifer calves $(\mathrm{n}=1,410)$

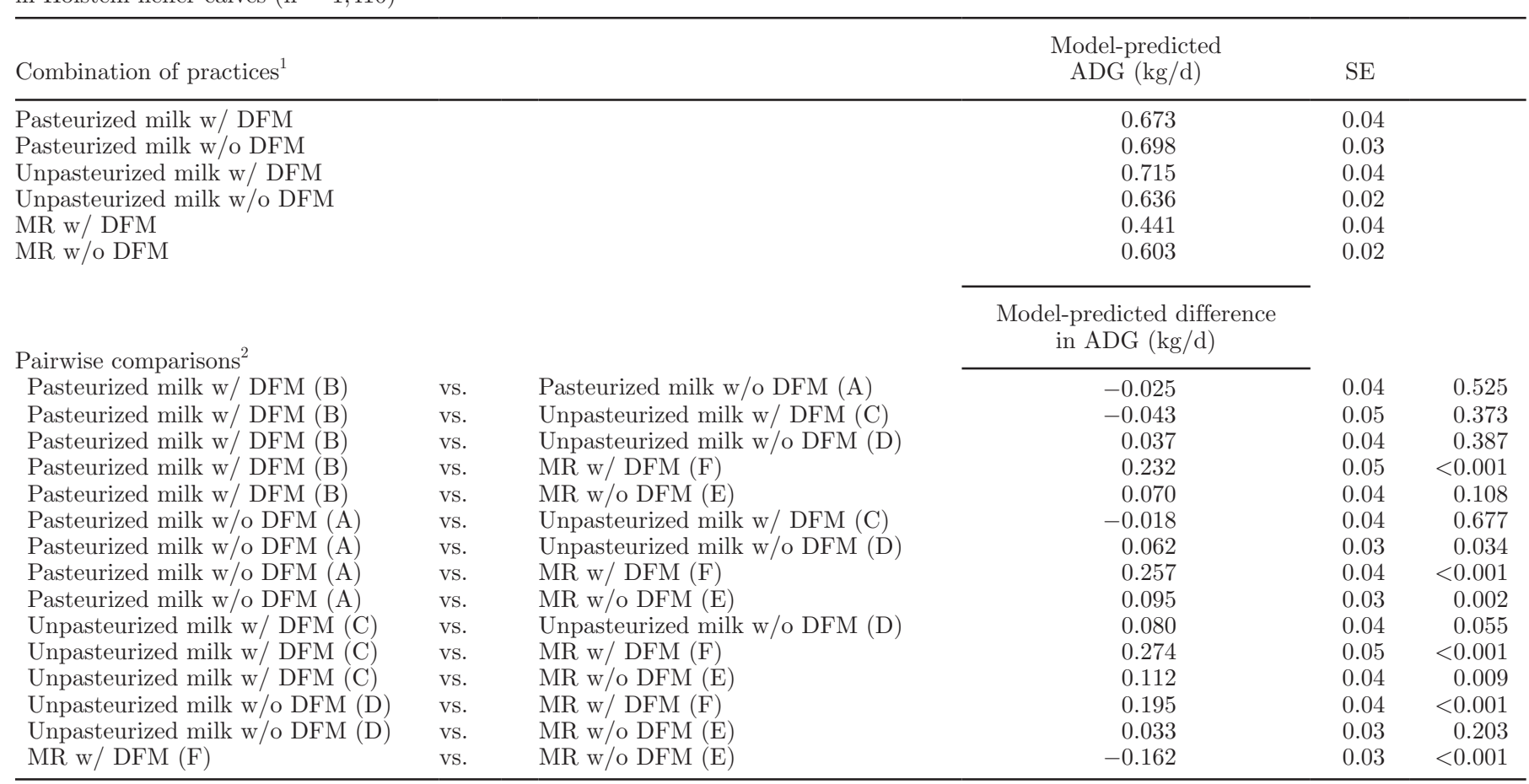

${ }^{1} \mathrm{DFM}=$ direct-fed microbial; $\mathrm{MR}=$ milk replacer; w/ = "with"; w/o = "without."

${ }^{2}$ Letters $(\mathrm{A}-\mathrm{F})$ correspond to combination of practices in Figure 2. 


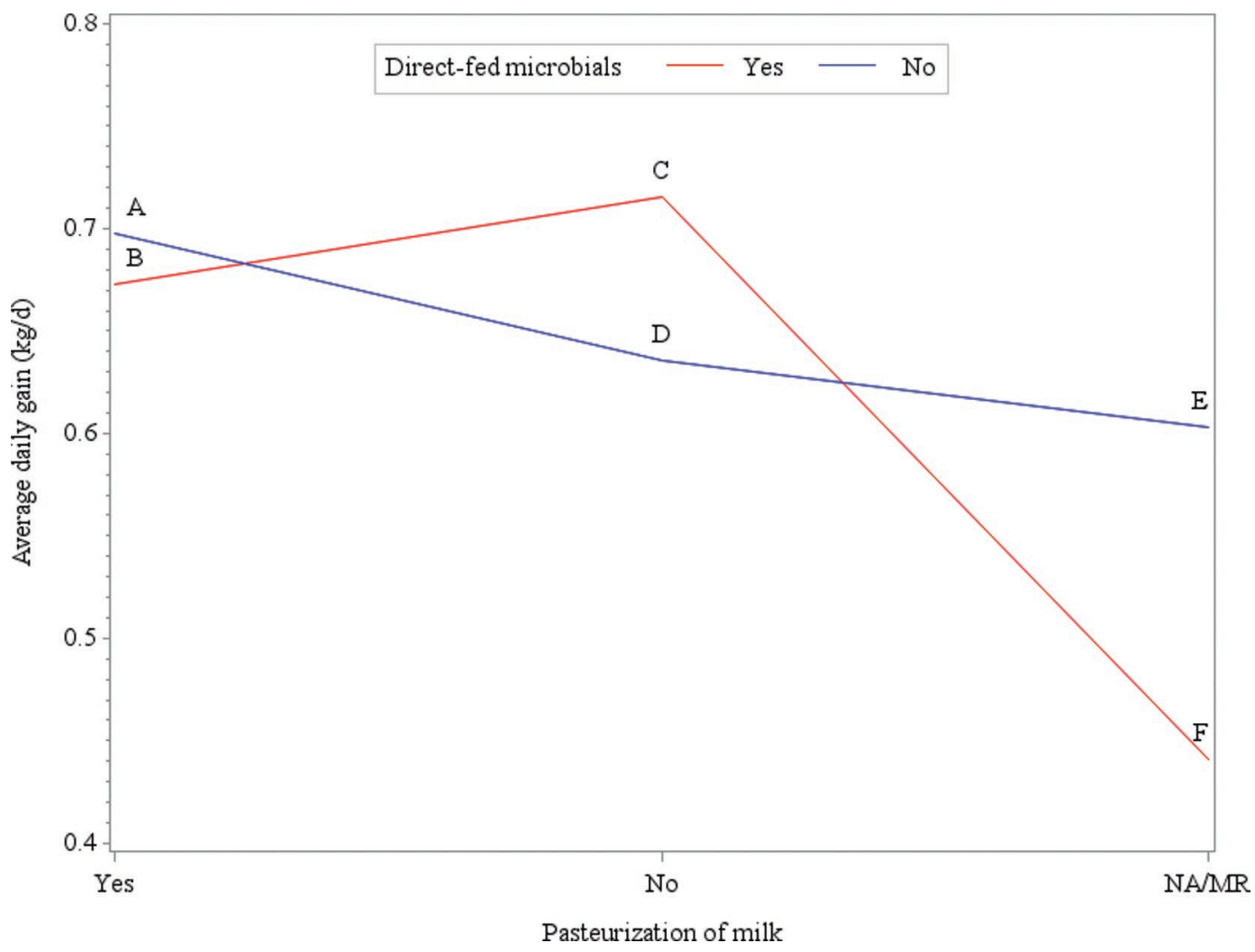

Figure 2. Graphical representation of the interaction between pasteurization of milk and direct-fed microbials for multivariable modeling of factors associated with ADG for Holstein heifer calves $(\mathrm{n}=1,410)$. Letters correspond to combinations of practices summarized in Table 5; NA/ $\mathrm{MR}=$ not applicable/milk replacer. Color version available online.

calves generally have significantly lower birth weights (Kertz et al., 1998; Hossein-Zadeh, 2010). Birth weight was included in the calculation for ADG, so it was not included in the model. The average birth weight for single calves was $43.3 \mathrm{~kg}$ (SE 0.14) and average birth weight for twin calves was $39.2 \mathrm{~kg}$ (SE 0.74). Research in beef cattle has shown that twin calves have lower birth weights and lower gains than single calves (Gregory et al., 1996). Another study showed that birth weight was a predictor for growth rates in calves (Lundborg et al., 2003). Although the calculation for ADG accounts for birth weight, it appears that twin calves are not able to maintain the same growth rate during the preweaning period as single calves.

Dam lactation was associated with ADG, with calves from first-calf heifers having significantly lower ADG than second-lactation or third- and higher-lactation dams. Because birth weight is positively associated with parity (Linden et al., 2009), larger cows tend to have larger calves (Swali and Wathes, 2006). As heifers are still growing during their first pregnancy, they typically have smaller calves at birth than second- or higherlactation cows (Losinger and Heinrichs, 1997). Calves with lower birth weights tended to gain less throughout the preweaning period and the first lactation (Swali and Wathes, 2006).

Calves that were fecal positive for Cryptosporidium and calves fecal positive for Giardia at the time of fecal sampling had significantly lower ADG than calves negative for Cryptosporidium or Giardia. Individual calf fecal samples were collected only once between 2 and 4 wk of age, so some of the calves that were not shedding Cryptosporidium or Giardia at the time of sampling might have been positive at some point during the preweaning period, likely decreasing the observed effect of Cryptosporidium and Giardia on ADG. Cryptosporidium infections occur early during the preweaning period (Santín et al., 2004), typically between 1 and 3 wk of age (average: $16 \mathrm{~d}$ of age; O'Handley et al., 1999). A longitudinal study showed that the prevalence of Cryptosporidium peaked at $2 \mathrm{wk}$ of age (Santín et al., 2008). Cryptosporidium infections cause damage to the brush border of enterocytes, leading to decreased absorptive capacity and osmotic diarrhea (Constable, 2014). Decreased absorption and diarrhea lead to decreased nutrient absorption and decreased ADG. Infections with Cryptosporidium can also be accompanied by depression, weakness, and anorexia. Giardia infections 
generally occur later in a calf's life (approximately 4 to 5 wk of age; Santín et al., 2009), and are associated with diarrhea (O'Handley et al., 1999). Cryptosporidi$u m$ is considered endemic in dairy herds in the United States (Garber et al., 1994), making on-farm hygiene important in disease control.

Because this was a nationwide field study, there were some limitations in study design. More producers were expected to participate in the study than actually did, making this a convenience sample rather than a nationally representative sample of dairy heifer management across the US dairy industry. Data collected on farm included self-reporting on the Calf Card, with some operations potentially reporting standard operating procedures and not necessarily individual calf-level data. One important piece of information that is associated with ADG is starter intake. This study did not collect information on individual calf starter intake due to the intense resources that would be needed to capture this information on a routine and consistent basis.

These results highlight the importance of feeding an appropriate quantity and quality of a liquid diet, keeping calves free from disease and comfortable, and mitigating the effects of temperature and humidity during the preweaning period, on ADG.

\section{ACKNOWLEDGMENTS}

Data are from a dissertation submitted to Colorado State University by C. B. Shivley in partial fulfilment of requirements for the $\mathrm{PhD}$ degree. Portions of this manuscript were presented at the 2015 and 2016 ADSA-ASAS Joint Annual Meetings. We thank the 104 dairy producers and their staff for participating in the study; the federal and state animal health personnel who assisted in collecting the data; Judy Rodriguez (USDA NAHMS, Fort Collins, CO) for technical assistance in data validation and analysis; Ashley Adams (Agricultural Science, Business, and Dairy Department, Morrisville State College, Morrisville, NY), Dan Catherman (Strauss Feeds, Watertown, WI), Jud Heinrichs (Department of Animal Science, Pennsylvania State University, University Park, PA), Robert James (Down Home Heifer Solutions Inc., Blacksburg, VA), Ken Leslie (Ontario Veterinary College, University of Guelph, Guelph, ON, Canada), Nina von Keyserlingk (Animal Welfare Program, Faculty of Land and Food Systems, University of British Columbia, Vancouver, British Columbia, Canada), and Daniel Weary (Animal Welfare Program, Faculty of Land and Food Systems, University of British Columbia, Vancouver, British Columbia, Canada) for their guidance in study design and analysis; Debbie Haines and the Saskatoon Colostrum Company for conducting the colostrum and serum test- ing; and Temple Grandin (Department of Animal Sciences, College of Agricultural Sciences, Colorado State University, Fort Collins) for assisting in funding C. B. Shivley during her $\mathrm{PhD}$ program.

\section{REFERENCES}

Abe, F., N. Ishibashi, and S. Shimamura. 1995. Effect of administration of bifidobacteria and lactic acid bacteria to newborn calves and piglets. J. Dairy Sci. 78:2838-2846.

Abu-Tarboush, H. M., M. Y. Al-Saiady, and A. H. Keir El-Din. 1996. Evaluation of diet containing lactobacilli on performance, fecal coliform, and lactobacilli of young dairy calves. Anim. Feed Sci. Technol. 57:39-49.

Adams, M. C., J. Luo, D. Rayward, S. King, R. Gibson, and G. H. Moghaddam. 2008. Selection of a novel direct-fed microbial to enhance weight gain in intensively reared calves. Anim. Feed Sci. Technol. 145:41-52.

Andreasen, S. N., and B. Forkman. 2012. The welfare of dairy cows is improved in relation to cleanliness and integument alterations on the hocks and lameness when sand is used as stall surface. J. Dairy Sci. 95:4961-4967.

Bach, A. 2011. Associations between several aspects of heifer development and dairy cow survivability to second lactation. J. Dairy Sci. 94:1052-1057.

Ballou, M. A., D. L. Hanson, C. J. Cobb, B. S. Obeidat, M. D. Sellers, A. R. Pepper-Yowell, J. A. Carroll, T. J. Earleywine, and S. D. Lawhon. 2015. Plane of nutrition influences the performance, innate leukocyte responses, and resistance to an oral Salmonella enterica serotype Typhimurium challenge in Jersey calves. J. Dairy Sci. 98:1972-1982.

BAMN. 2003. A guide to dairy calf feeding and management. Bovine Alliance on Management and Nutrition (BAMN). Accessed Sep. 9, 2016. https://www.aphis.usda.gov/animal_health/nahms/dairy/ downloads/bamn/BAMN03_GuideFeeding.pdf.

BAMN. 2011. Direct-fed microbials (probiotics) in calf diets. Bovine Alliance on Management and Nutrition (BAMN). Accessed Mar. 1, 2016. https://www.aphis.usda.gov/animal_health/nahms/ dairy/downloads/bamn/BAMN11_Probiotics.pdf.

BAMN. 2017. A guide to feeding and weaning healthy and productive dairy calves. Bovine Alliance on Management and Nutrition (BAMN). Accessed Mar. 1, 2016. https://www.aphis.usda .gov/animal_health/nahms/dairy/downloads/bamn/BAMN17 _GuideFeeding.pdf.

Beede, D. K., and R. J. Collier. 1986. Potential nutritional strategies for intensively managed cattle during thermal stress. J. Anim. Sci. 62:543-554.

Blome, R. M., J. K. Drackley, F. K. McKeith, M. F. Hutjens, and G. C. McCoy. 2003. Growth, nutrient utilization, and body composition of dairy calves fed milk replacers containing different amounts of protein. J. Anim. Sci. 81:1641-1655.

Broucek, J., P. Kisac, and M. Uhrincat. 2009. Effect of hot temperatures on the hematological parameters, health and performance of calves. Int. J. Biometeorol. 53:201-208.

Camiloti, T. V., J. A. Fregonesi, M. A. G. von Keyserlingk, and D. M. Weary. 2012. Short communication: Effects of bedding quality on the lying behavior of dairy calves. J. Dairy Sci. 95:3380-3383.

Chester-Jones, H., and P. C. Hoffman. 2003. Calf nutrition. Pages $21-$ 36 in Raising Dairy Replacements. P. C. Hoffman, and R. Plourd, ed. Midwest Plan Service, Ames, IA.

Collier, R. J., R. B. Zimbelman, R. P. Rhoads, M. L. Rhoads, and L. H. Baumgard. 2011. A re-evaluation of the impact of temperature humidity index (THI) and black globe humidity index (BGHI) on milk production in high producing dairy cows. Pages $113-125$ in Proc. Western Dairy Management Conf., Reno, NV.

Constable, P. D. 2014. Overview of Cryptosporidiosis: Cryptosporidiosis. Merck Veterinary Manual. Accessed Mar. 1, 2016. https:// www.merckvetmanual.com/digestive-system/cryptosporidiosis / overview-of-cryptosporidiosis. 
Curtis, G. 2015. The impact of neonatal nutrition on the health, welfare and productivity of Holstein dairy calves. Doctoral thesis. University of Liverpool, UK.

De Paula Vieira, A., V. Guesdon, A. M. de Passillé, M. A. G. von Keyserlingk, and D. M. Weary. 2008. Behavioural indicators of hunger in dairy calves. Appl. Anim. Behav. Sci. 109:180-189.

Donovan, G. A., I. R. Dohoo, D. M. Montgomery, and F. L. Bennett. 1998. Calf and disease factors affecting growth in female Holstein calves in Florida, USA. Prev. Vet. Med. 33:1-10.

Drackley, J. K. 2008. Calf nutrition from birth to breeding. Vet. Clin. North Am. Food Anim. Pract. 24:55-86.

Flower, F. C., and D. M. Weary. 2001. Effects of early separation on the dairy cow and calf. Appl. Anim. Behav. Sci. 70:275-284.

Garber, L. P., M. D. Salman, H. S. Hurd, T. Keefe, and J. L. Schlater. 1994. Potential risk factors for Cryptosporidium infection in dairy calves. J. Am. Vet. Med. Assoc. 205:86-91.

Godden, S. M., J. P. Fetrow, J. M. Feirtag, L. R. Green, and S. J. Wells. 2005. Economic analysis of feeding pasteurized nonsaleable milk versus conventional milk replacer to dairy calves. J. Am. Vet. Med. Assoc. 226:1547-1554. https://doi.org/10.2460/javma.2005 .226 .1547 .

Goff, J. P. 2006. Major advances in our understanding of nutritional influences on bovine health. J. Dairy Sci. 89:1292-1301.

Gregory, K. E., S. E. Echternkamp, and L. V. Cundiff. 1996. Effects of twinning on dystocia, calf survival, calf growth, carcass traits, and cow productivity. J. Anim. Sci. 74:1223-1233.

Heinrichs, A. J. 1993. Raising dairy replacements to meet the needs of the 21st century. J. Dairy Sci. 76:3179-3187.

Heinrichs, A. J., G. W. Rogers, and J. B. Cooper. 1992. Predicting body weight and wither height in Holstein heifers using body measurements. J. Dairy Sci. 75:3576-3581.

Higginbotham, G. E., J. D. Robison, E. R. Atwill, M. Das Gracas, C. Pereira, A. Dean Howes, and J. R. Males. 1998. Effect of a directfed microbial product on calf performance and fecal flora. Prof. Anim. Sci. 14:108-113.

Hill, T. M., J. M. Aldrich, R. L. Schlotterbeck, and H. G. Bateman. 2007. Amino acids, fatty acids, and fat sources for calf milk replacers. Prof. Anim. Sci. 23:401-408.

Hill, T. M., H. G. Bateman, J. M. Aldrich, and R. L. Schlotterbeck. 2009. Effect of consistency of nutrient intake from milk and milk replacer on dairy calf performance. Prof. Anim. Sci. 25:85-92.

Hill, T. M., H. G. Bateman, J. M. Aldrich, and R. L. Schlotterbeck. 2011. Comparisons of housing, bedding, and cooling options for dairy calves. J. Dairy Sci. 94:2138-2146.

Hossein-Zadeh, N. G. 2010. The effect of twinning on milk yield, dystocia, calf birth weight and open days in Holstein dairy cows of Iran. J. Anim. Physiol. Anim. Nutr. (Berl.) 94:780-787.

Jasper, J., and D. M. Weary. 2002. Effects of ad libitum milk intake on dairy calves. J. Dairy Sci. 85:3054-3058.

Jenny, B. F., H. J. Vandijk, and J. A. Collins. 1991. Performance and fecal flora of calves fed a bacillus subtilis concentrate. J. Dairy Sci. 74:1968-1973.

Jorgensen, M. A., P. C. Hoffman, and A. J. Nytes. 2006. Case study: A field survey of on-farm milk pasteurization efficacy. Prof. Anim. Sci. 22:472-476.

Kertz, A. F., B. A. Barton, and L. F. Reutzel. 1998. Relative efficiencies of wither height and body weight increase from birth until first calving in Holstein cattle. J. Dairy Sci. 81:1479-1482.

Kertz, A. F., L. F. Reutzel, and J. H. Mahoney. 1984. Ad libitum water intake by neonatal calves and its relationship to calf starter intake, weight gain, feces score, and season. J. Dairy Sci. 67:2964-2969.

LeBlanc, S. J., K. D. Lissemore, D. F. Kelton, T. F. Duffield, and K. E. Leslie. 2006. Major advances in disease prevention in dairy cattle. J. Dairy Sci. 89:1267-1279.

Li, H., Q. Y. Diao, N. F. Zhang, and Z. Y. Fan. 2008. Growth, nutrient utilization and amino acid digestibility of dairy calves fed milk replacers containing different amounts of protein in the preruminant period. Asian-australas. J. Anim. Sci. 21:1151-1158.

Liang, Y. L., J. A. Carroll, and M. A. Ballou. 2015a. Plane of milk replacer nutrition influences the resistance to an oral Citrobacter freundii opportunistic infection in Jersey calves at 10 days of age. J. Dairy Sci. 98(Suppl. 2):743. (Abstr.)

Liang, Y. L., T. L. Harris, J. A. Carroll, and M. A. Ballou. 2015b. Gastrointestinal tract of healthy 1-week-old Jersey calves is well suited to digest, absorb, and incorporate nutrients into lean tissue even when fed a high plane of milk replacer. J. Dairy Sci. 98(Suppl. 2):736. (Abstr.)

Linden, T. C., R. C. Bicalho, and D. V. Nydam. 2009. Calf birth weight and its association with calf and cow survivability, disease incidence, reproductive performance, and milk production. J. Dairy Sci. 92:2580-2588

Lombard, J. E., C. B. Tucker, M. A. G. von Keyserlingk, C. A. Kopral, and D. M. Weary. 2010. Associations between cow hygiene, hock injuries, and free stall usage on US dairy farms. J. Dairy Sci. 93:4668-4676.

Losinger, W. C., and A. J. Heinrichs. 1997. An analysis of age and body weight at first calving for Holsteins in the United States. Prev. Vet. Med. 32:193-205.

Lundborg, G. K., P. A. Oltenacu, D. O. Maizon, E. C. Svensson, and P. G. A. Liberg. 2003. Dam-related effects on heart girth at birth, morbidity and growth rate from birth to 90 days of age in Swedish dairy calves. Prev. Vet. Med. 60:175-190.

Mogensen, L., C. C. Krohn, J. T. Sørensen, J. Hindhede, and L. H. Nielsen. 1997. Association between resting behaviour and live weight gain in dairy heifers housed in pens with different space allowance and floor type. Appl. Anim. Behav. Sci. 55:11-19.

Morrill, J. L., J. M. Morrill, A. M. Feyerherm, and J. F. Laster. 1995. Plasma proteins and a probiotic as ingredients in milk replacer. J. Dairy Sci. 78:902-907.

NRC. 2001. Nutrient Requirements of Dairy Cattle. 7th rev. ed. National Academies Press, Washington, DC.

NOAA. 2016. Quality controlled local climatological data (QCLCD). Accessed Mar. 1, 2016. https://www.ncdc.noaa.gov/data-access/ land-based-station-data/land-based-datasets/quality-controlled -local-climatological-data-qclcd.

Nonnecke, B. J., M. R. Foote, B. L. Miller, M. Fowler, T. E. Johnson, and R. L. Horst. 2009. Effects of chronic environmental cold on growth, health, and select metabolic and immunologic responses of preruminant calves. J. Dairy Sci. 92:6134-6143.

Nonnecke, B. J., M. R. Foote, J. M. Smith, B. A. Pesch, and M. E. Van Amburgh. 2003. Composition and functional capacity of blood mononuclear leukocyte populations from neonatal calves on standard and intensified milk replacer diets. J. Dairy Sci. 86:35923604 .

O'Handley, R. M., C. Cockwill, T. A. McAllister, M. Jelinski, D. W. Morck, and M. E. Olson. 1999. Duration of naturally acquired giardiosis and cryptosporidiosis in dairy calves and their association with diarrhea. J. Am. Vet. Med. Assoc. 214:391-396.

Owens, F. N., P. Dubeski, and C. F. Hanson. 1993. Factors that alter the growth and development of ruminants. J. Anim. Sci. 71:31383150 .

Panivivat, R., E. B. Kegley, J. A. Pennington, D. W. Kellogg, and S. L. Krumpelman. 2004. Growth performance and health of dairy calves bedded with different types of materials. J. Dairy Sci. $87: 3736-3745$

Place, N. T., A. J. Heinrichs, and H. N. Erb. 1998. The effects of disease, management, and nutrition on average daily gain of dairy heifers from birth to four months. J. Dairy Sci. 81:1004-1009.

Rincker, L. D., M. J. VandeHaar, C. A. Wolf, J. S. Liesman, L. T. Chapin, and M. W. Nielsen. 2011. Effect of intensified feeding of heifer calves on growth, pubertal age, calving age, milk yield, and economics. J. Dairy Sci. 94:3554-3567.

Roland, L., M. Drillich, D. Klein-Jöbstl, and M. Iwersen. 2016. Invited review: Influence of climatic conditions on the development, performance, and health of calves. J. Dairy Sci. 99:2438-2452.

Santín, M., J. M. Trout, and R. Fayer. 2008. A longitudinal study of cryptosporidiosis in dairy cattle from birth to 2 years of age. Vet. Parasitol. 155:15-23.

Santín, M., J. M. Trout, and R. Fayer. 2009. A longitudinal study of Giardia duodenalis genotypes in dairy cows from birth to 2 years of age. Vet. Parasitol. 162:40-45. 
Santín, M., J. M. Trout, L. Xiao, L. Zhou, E. Greiner, and R. Fayer. 2004. Prevalence and age-related variation of Cryptosporidium species and genotypes in dairy calves. Vet. Parasitol. 122:103-117.

Sharon, K. P., Y. L. Liang, N. C. Burdick Sanchez, J. A. Carroll, P. R. Broadway, and M. A. Ballou. 2015a. Preweaning plane of nutrition and Mannheimia haemolytica dose influence metabolic responses to a combined bovine herpesvirus-1 and Mannheimia haemolytica challenge in post-weaned Holstein calves. J. Dairy Sci. 98(Suppl. 2):627. (Abstr.)

Sharon, K. P., Y. L. Liang, N. C. Burdick Sanchez, J. A. Carroll, P. R. Broadway, and M. A. Ballou. 2015b. Preweaning plane of nutrition and Mannheimia haemolytica dose influence inflammatory responses to a combined bovine herpesvirus-1 and Mannheimia haemolytica challenge in postweaned Holstein calves. J. Dairy Sci. 98(Suppl. 2):193. (Abstr.)

Soberon, F., E. Raffrenato, R. W. Everett, and M. E. Van Amburgh. 2012. Preweaning milk replacer intake and effects on long-term productivity of dairy calves. J. Dairy Sci. 95:783-793.

Soberon, F., and M. E. Van Amburgh. 2013. Lactation Biology Symposium: The effect of nutrient intake from milk or milk replacer of preweaned dairy calves on lactation milk yield as adults: A metaanalysis of current data. J. Anim. Sci. 91:706-712.

Stull, C., and J. Reynolds. 2008. Calf welfare. Vet. Clin. North Am. Food Anim. Pract. 24:191-203.

Swali, A., and D. C. Wathes. 2006. Influence of the dam and sire on size at birth and subsequent growth, milk production and fertility in dairy heifers. Theriogenology 66:1173-1184.

Terré, M., C. Tejero, and A. Bach. 2009. Long-term effects on heifer performance of an enhanced-growth feeding programme applied during the preweaning period. J. Dairy Res. 76:331-339.
Thickett, W. S., D. Mitchell, and B. Hallows. 1986. Calf Rearing. Farming Press, Ipswich, UK.

Timmerman, H. M., L. Mulder, H. Everts, D. C. van Espen, E. van der Wal, G. Klaassen, S. M. G. Rouwers, R. Hartemink, F. M Rombouts, and A. C. Beynen. 2005. Health and growth of veal calves fed milk replacers with or without probiotics. J. Dairy Sci. $88: 2154-2165$.

Urie, N. J., J. E. Lombard, C. B. Shivley, C. A. Kopral, A. E. Adams, T. J. Earleywine, J. D. Olson, and F. B. Gary. 2018. Preweaned heifer management on US dairy operations: Part I. Descriptive characteristics of preweaned heifer raising practices. J. Dairy Sci 101:9168-9184. https://doi.org/10.3168/jds.2017-14010.

USDA. 2016. National Animal Health Monitoring System (NAHMS). Accessed Mar. 29, 2016. https://www.aphis.usda.gov/animal _health/nahms.

Van Amburgh, M. E., F. Soberon, J. Karszes, and R. W. Everett. 2014. Early life nutrition and management impacts long-term productivity of calves. Pages 35-49 in Proc. 50th Florida Dairy Prod. Conf., Gainesville, FL. University of Florida, Gainesville, FL.

Virtala, A. M., G. D. Mechor, Y. T. Gröhn, and H. N. Erb. 1996 The effect of calfhood diseases on growth of female dairy calves during the first 3 months of life in New York State. J. Dairy Sci. 79:1040-1049.

West, J. W. 2003. Effects of heat-stress on production in dairy cattle J. Dairy Sci. 86:2131-2144.

Worth, G. M., K. E. Schütz, M. Stewart, V. M. Cave, M. Foster, and M. A. Sutherland. 2015. Dairy calves' preference for rearing substrate. Appl. Anim. Behav. Sci. 168:1-9. 